Jurnal Pemberdayaan: Publikasi Hasil Pengabdian kepada Masyarakat

Vol. 2, No. 2,Agustus 2018, Hal. 265-274

ISSN: 2088 4559; e-ISSN: XXXX-XXXX

DOI:

\title{
WISATA OUTBOUND DI GUNUNG GENTONG GEDANGSARI GUNUNG KIDUL
}

\author{
Tri Wahyuni Sukesi ${ }^{1}$, Sulistyawati ${ }^{1}$, Surahma Asti Mulasari ${ }^{1}$, Fatwa Tentama ${ }^{2}$ \\ Fakultas Kesehatan Masyarakat Universitas Ahmad Dahlan ${ }^{1}$ \\ Fakultas Psikologi Universitas Ahmad Dahlan ${ }^{2}$ \\ yunisukesi.fkmuad@gmail.com
}

\begin{abstract}
ABSTRAK
Wisata budaya dan alam saat ini sedang banyak digemari oleh masyarakat. Wisata outbound adalah salah satu dari wisata budaya dan alam yang sedang banyak berkembang saat ini. Upaya untuk mengurangi tekanan pekerjaan dan hidup banyak sekali orang mencari tujuan wisata outbound yang murah. Salah satu tujuan yang ada di wilayah Gunung Kidul adalah Gunung Gentong, akan tetapi tujuan wisata outbound ini belum digarap dengan maksimal sehingga perlu dilakukan beberapa pelatihan bagi pengelolanya khususnya pelatihan permainan outbound yang berbasis pada dolanan anak di gunung Gentong. Metode yang digunakan adalah dengan pelatihan outbound yang berbasis pada dolanan anak tradisional secara langsung kepada pengelola wisata. Memberikan sumbangan peralatan yang digunakan dalam permainan permainan tersebut. Melakukan monitoring evaluasi setelah pelaksanaan pelatihan. Hasil yang diperoleh adalah kegiatan pelatihan berjalan dengan baik dan peserta aktif bertanya dan mengikuti kegiatan pelatihan sampai selesai. Pelatihan dilakukan dengan interaktif antara narasumber dengan peserta pelatihan.
\end{abstract}

Kata kunci: wisata, outbound, pelatihan

\begin{abstract}
Cultural and natural tourism is currently being favored by many people. Outbound tourism is one of the many cultural and natural attractions that are currently developing. Efforts to reduce the pressure of work and life are very many people looking for cheap outbound tourist destinations. One of the objectives in the Gunung Kidul region is Gunung Gentong, but this outbound tourism destination has not been worked out to the maximum so it is necessary to do some training for managers especially training outbound games based on children's toys on Gunung Gentong. The method used is outbound training based on traditional children's toys directly to tourist managers. Giving donations of equipment used in the game. Monitoring evaluations after training. The results obtained were that the training activities went well and the active participants asked questions and attended the training activities to completion. The training was conducted interactively between resource persons and training participants.
\end{abstract}

Keywords: tourism, outbound, training 


\section{PENDAHULUAN}

Peningkatan kualitas masyarakat merupakan salah satu hal yang penting dalam peningkatan Indeks Pembangunan Manusia (Human Development Index) di Indonesia. Pemanfaatan potensi alam yang ada dengan memanfaatkan teknologi terkini, akan menjadi peluang bagi berbagai upaya peningkatan kualitas masyarakat (Suripto, 2011). Seperti halnya daerah Gunung Kidul yang terus berbenah dan mengembangkan diri untuk bisa menjadi kabupaten yang memiliki tingkat kesejahteraan yang lebih baik. Kondisi Kabupaten Gunung Kidul yang banyak terdiri dari tanah karst cenderung tidak terlalu menguntungkan di sektor pertanian. Pada musim kemarau tanah tidak dapat menyimpan air sehingga banyak terjadi kekeringan dan kegagalan dalam panen. Hal ini yang menyebabkan Kabupaten Gunung Kidul memiliki tingkat kesejahteran yang lebih rendah dibandingkan Kota Yogyakarta (BPS \& Kominfo, 2016).

Sektor lain yang sedang dikembangkan di Kabupaten Gunung Kidul untuk dapat meningkatkan tingkat kesejahteraan masyarakat adalah sektor wisata. Sektor wisata ini diharapkan dapat meningkatkan ekonomi masyarakat dan menjadi alternatif mata pencaharian selain dari pertanian (Adinugroho, 2017). Daerah Gunung Kidul yang terbagi menjadi 3 zona yaitu zona utara, tengah dan selatan memiliki keistimewaan yang layak untuk dijadikan tujuan wisata. Zona Utara disebut wilayah Batur Agung dengan ketinggian $200 \mathrm{~m}-700 \mathrm{~m}$ di atas permukaan laut. Keadaannya berbukit-bukit, terdapat sumber-sumber air tanah kedalaman 6 m-12 m dari permukaan tanah. Jenis tanah didominasi latosol dengan batuan induk vulkanik dan sedimen taufan. Wilayah ini meliputi Kecamatan Patuk, Gedangsari, Nglipar, Ngawen, Semin, dan Kecamatan Ponjong bagian utara. Zona Tengah disebut wilayah pengembangan Ledok Wonosari, dengan ketinggian 150 m - 200 mdpl (Pemkab Gunungkidul, 2016). Jenis tanah didominasi oleh asosiasi mediteran merah dan grumosol hitam dengan bahan induk batu kapur. Hal tersebut menyebabkan meskipun musim kemarau panjang, partikel-partikel air masih mampu bertahan. Terdapat sungai di atas tanah, tetapi di musim kemarau kering. Wilayah ini meliputi Kecamatan Playen, Wonosari, Karangmojo, Ponjong bagian tengah dan Kecamatan Semanu bagian utara. Zona Selatan disebut wilayah pengembangan Gunung Seribu (Duizon gebergton atau Zuider gebergton), dengan ketinggian $0 \mathrm{~m}-300 \mathrm{mdpl}$. Batuan dasar pembentuknya adalah batu kapur dengan ciri khas bukit-bukit kerucut (Conical limestone) dan merupakan kawasan karst. Pada wilayah ini banyak dijumpai sungai bawah tanah. Zone Selatan ini meliputi Kecamatan Saptosari, Paliyan, Girisubo, Tanjungsari, Tepus, Rongkop, Purwosari, 
Panggang, Ponjong bagian selatan, dan Kecamatan Semanu bagian selatan (Pemkab Gunungkidul, 2016). Destinasi wisata yang banyak dikembangkan di Gunung Kidul adalah pantai, gua dan pegunungan yang memberikan pemandangan yang indah dan menarik untuk berswafoto (Nafisah \& Sukarniati, 2015).

Salah satu tujuan wisata yang sedang dikembangkan adalah Gunung Gentong yang terletak di Desa Ngalang Gedangsari Gunung Kidul. Obyek wisata ini menawarkan pemandangan yang bagus jika dilihat dari Gunung Gentong. Gunung Gentong belum lama di jadikan tempat wisata untuk menyedot wisatawan ke Gunungkidul. Gunung Gentong ini terletak di dusun Manggung, desa Ngalang, kecamatan Gedangsari, kabupaten Gunungkidul. Gunung Gentong ini biasanya digunakan masyarakat setempat untuk nyadran, dan konon katanya Gunung Gentong ini pernah disinggahi oleh Prabu Brawijaya V. Pada hari tertentu dan bulan tertentu biasanya Gunung Gentong ini digunakan untuk upacara adat. Kentalnya sisi budaya ini menjadikan daerah ini sangat potensial untuk dikembangkan beberapa aspek budaya dan lingkungan seperti permainan tradisional dan upaya pemanfaatan lingkungan untuk meningkatkan daya tarik wisata budaya Gunung Gentong (Irwanto, 2017).
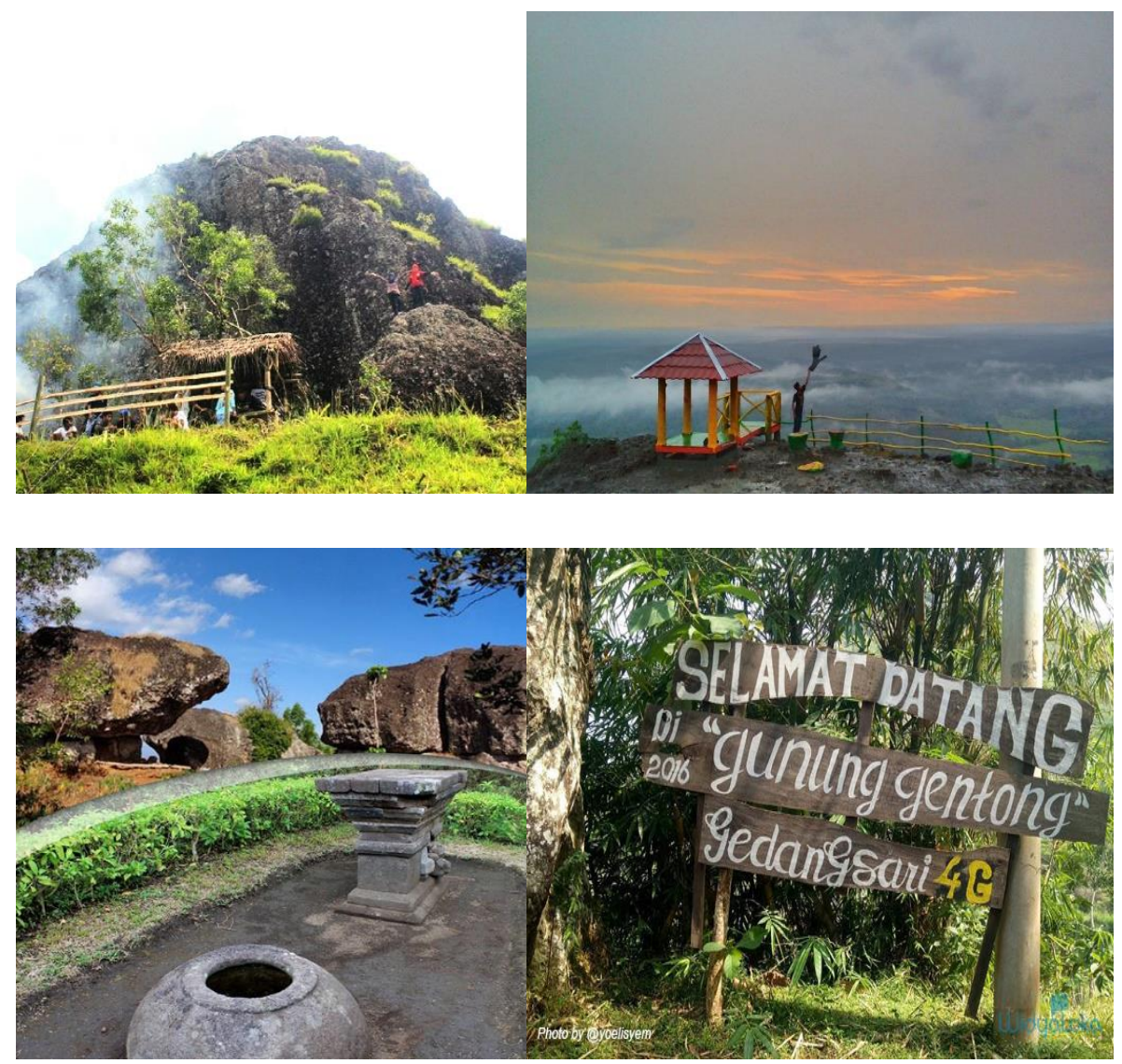

Gambar 1. Kondisi lingkungan Dusun Manggung Gedangsari (Irwanto, 2017) 
Sebagai lokasi tujuan wisata yang baru muncul di Gunung Kidul, Gunung Gentong memerlukan sentuhan pengelolaan yang baik dari warga pengelolanya. Persoalan prioritas mitra adalah adanya potensi yang belum terorganisir dengan baik. Potensi tersebut baik budaya (dolanan anak) maupun potensi fisik (gunung dan sekitarnya sebagai lokasi outbound). Dari gambaran di atas diperlukan peningkatan sumber daya manusia (SDM) yang trampil untuk mengelola tempat wisata tersebut. Kegiatan pengabdian kepada masyarakat (PKM) ini menitikberatkan kegiatannya pada pelatihan berbagai permainan tradisional untuk wisata outbound di lokasi wisata Gunung Gentong. Dipilih wisata outbound karena wisata outbound sekarang ini sedang banyak dikembangkan di Yogyakarta. Wisata outbound menawarkan sesuatu yang dapat dinikmati bersama-sama baik keluarga atau instansi kerja. Banyak instansi kerja atau keluarga yang memilih wisata outbound untuk meningkatkan hubungan kerja sama dalam pekerjaan, meningkatkan hubungan baik, meningkatkan kinerja, melatih kepemimpinan, strategi kerja dan menurunkan tingkat stress melalui permainan yang ditawarkan dalam kegiatan selama outbound (Falah, 2014).

Dipilih dolanan anak sebagai pengisi kegiatan wisata outbound karena dolanan anak tradisional sudah mulai hilang di masyarakat, sehingga diharapkan dapat melestarikan dolanan anak tradisional. Selain itu dolanan anak tradisional memiliki nilai-nilai positif yang dapat meningkatkan keeratan hubungan sosial yang baik, kerjasama, strategi, kepemimpinan dan sportifitas tanpa menghilangkan keseruan dan keasikan jika dilakukan bersama sama (Sari, 2016). Hal inilah yang menjadi program utama yang dilakukan dalam kegiatan pengabdian kepada masyarakat ini. Harapannya adalah Gunung Gentong dapat dikelola dengan baik tidak hanya menawarkan pemandangan yang indah tetapi pengelolanya dapat menawarkan wisata outbound yang murah, menarik dan penuh dengan nilai-nilai budaya.

\section{METODE}

Metode pendekatan yang ditawarkan untuk mengatasi permasalahan mitra adalah dengan pemberdayaan masyarakat, pelatihan, pendampingan, dan penyediaan sarana prasarana sebagai stimulasi pengelolaan wisata budaya dan alam di Dusun Manggung Ngalang Gedangsari. Alat dan bahan yang digunakan dan selanjutnya disumbangkan kepada mitra adalah permainan ular tangga raksasa lengkap dengan dadu, bola plastik, terompak panjang, goni untuk balapan karung sejumlah 4 buah, ember sebanyak 4 buah, ban bekas sebanyak 4 buah untuk permainan lorong panjang dan juga 4 buah egrang. 
Prosedur kerja untuk mendukung realisasi metode dilakukan sosialisasi program PKM, pelatihan model dolanan anak, pelatihan diberikan oleh ahli kepada mitra dengan tujuan untuk menguasai berbagai model dolanan anak (permainan tradisional) yang ada di Indonesia, pembuatan wahana outbound, pemberdayaan masyarakat untuk membuat wahana outbound, monitoring dan evaluasi untuk memastikan program berjalan dengan baik sesuai tujuan kegiatan.

\section{HASIL, PEMBAHASAN, DAN DAMPAK}

Kegiatan PKM ini dilakukan di rest area Kecamatan Gedangsari pada tanggal 1 November 2018, sedangkan pendampingan dilakukan pada 8 dan 15 November 2018. Peserta adalah remaja pengelola obyek wisata Gunung Gentong. Pelaksanaan kegiatan adalah training of traineer untuk pengelola outbound di daerah wisata Gunung Gentong. Gambar 1-7 merupakan foto foto kegiatan selama pelaksanaan pengabdian.

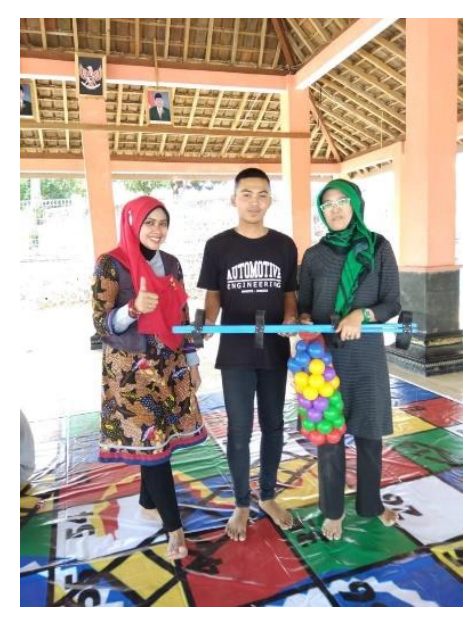

Gambar 1. Serah Terima Alat Secara Simbolis dari Tim Pengabdi kepada Ketua Forum Remaja Pengelola Gunung Gentong



Gambar 2. Pembukaan dan perkenalan tim dengan peserta pelatihan 

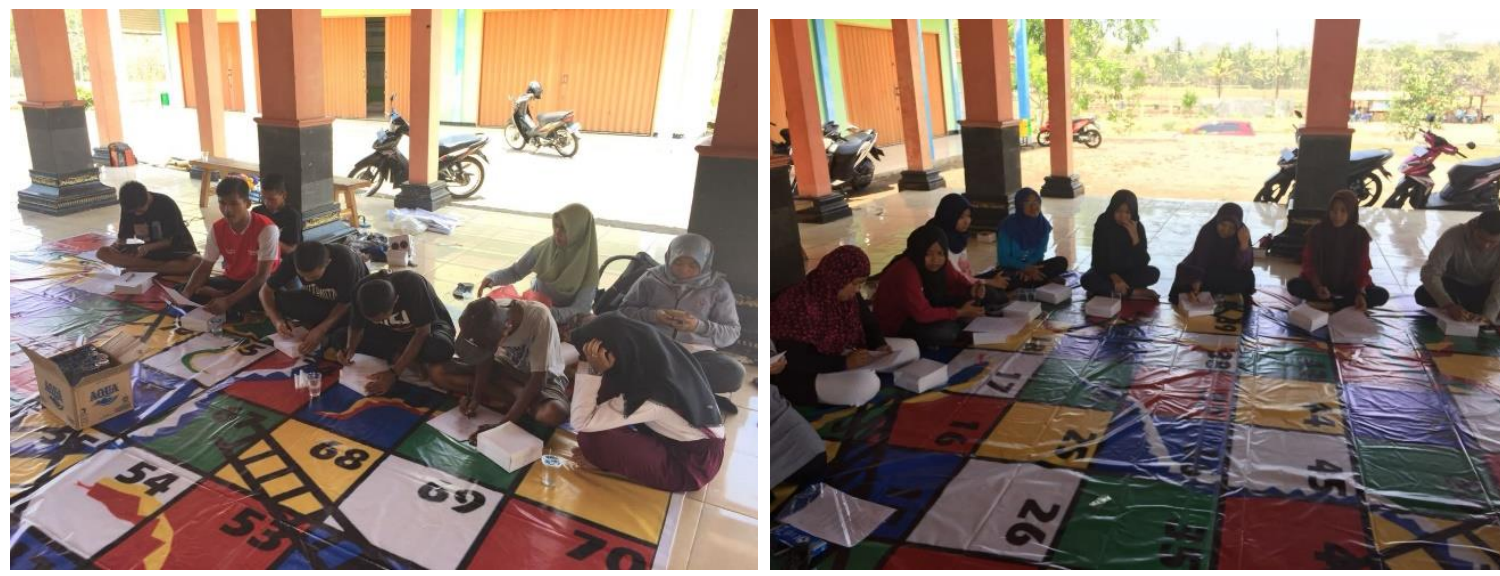

Gambar 3. Peserta diminta untuk mengisi kuesioner sebelum dilakukan pelatihan.

Data yang diambil adalah tentang tingkat stress pada peserta pelatihan. Data yang diambil sebelum pelatihan menjadi data pre yang selanjutnya akan dibandingkan dengan data post setelah peserta mengikuti rangkaian pelatihan. Berdasarkan data pre dan post tersebut akan dilihat efektivitas pelatihan outbound tersebut terhadap tingkat stress.

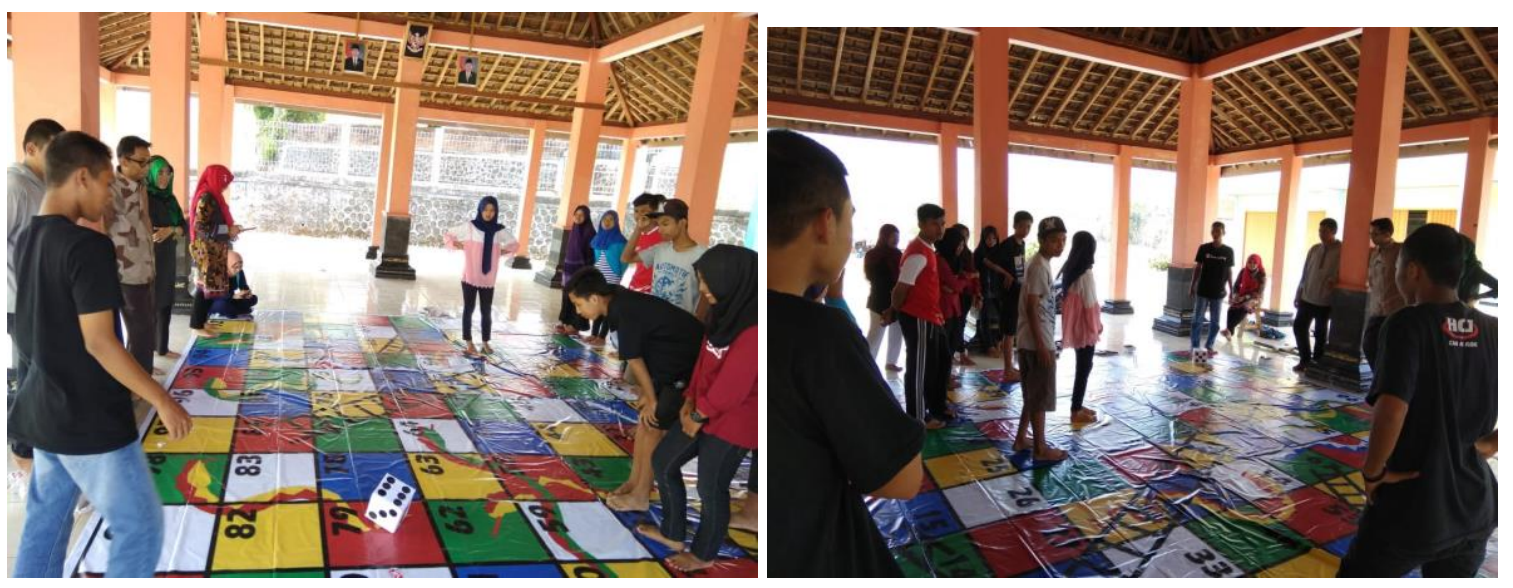

Gambar 4. Pelatihan dengan Menggunakan Ular Tangga Raksasa



Gambar 5. Pelatihan dengan Menggunakan Terompak Ajaib 

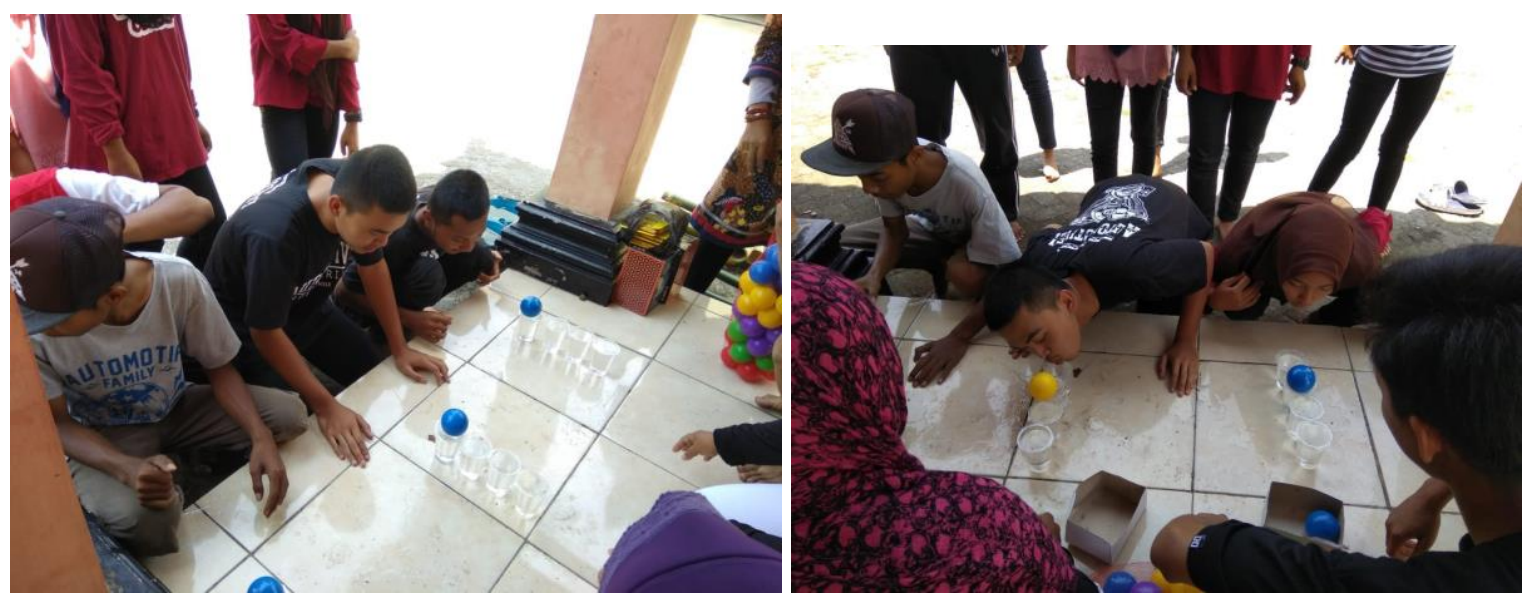

Gambar 6. Pelatihan dengan Menggunakan Bola Luncur Air
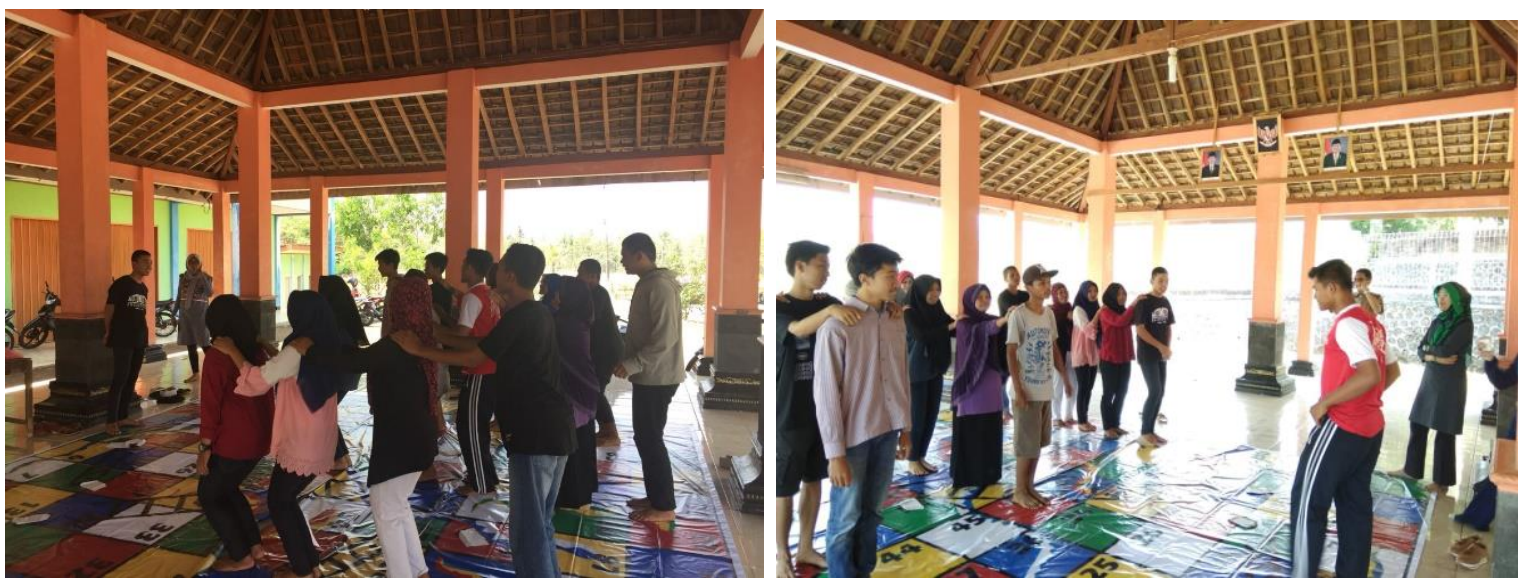

Gambar 7. Mengajari Peserta Untuk Melakukan Ice Breaking

Pelatihan yang diberikan sebagian besar merupakan permainan permainan yang dapat diaplikasikan di acara outbound. Permainan lebih ditekankan pada permainan tradisional tetapi memiliki makna yang cukup dalam untuk membangun ketahanan fisik, kerjasama tim, strategi dan kedisiplinan akan tetapi tetap dapat dilakukan dengan cara yang menyenangkan sehingga peserta outbound nantinya tidak bosan.

Secara keseluruhan pelaksanaan kegiatan dapat berjalan dengan lancar, semua peserta aktif mengikuti pelatihan dan bersemangat untuk menindaklanjuti dalam memenuhi fasilitas outbound yang ditawarkan di obyek wisata Gunung Gentong. Kegiatan pelatihan outbound ini bertujuan untuk meningkatkan keterampilan remaja pengelola kawasan wisata Gunung Gentong. Jenis-jenis permainan yang dipilih adalah permainan tradisional dan mudah dilaksanakan oleh segala usia. Permainan tradisional dipilih untuk melestarikan budaya dolanan anak-anak yang memang sudah jarang dilakukan. Bahan-bahan yang digunakan dalam permainan ini juga merupakan bahan alam atau bahan bekas yang didaur ulang untuk dapat 
mendukung keseruan permainan outbound ini. Bahan alam yang digunakan adalah bambu, kayu dan bahan bekas yang digunakan adalah goni, gelas plastik kemasan, ban bekas dan bola plastik dari hasil daur ulang.

\section{SIMPULAN}

Kegiatan pengabdian masyarakat di Dusun Manggung Ngalang dapat berjalan dengan baik dan lancar. Peserta antusias dan dapat bekerjasama dengan baik. Peralatan yang disumbangkan juga digunakan oleh peserta untuk memajukan wisata outbound di Gunung Gentong.

\section{DAFTAR PUSTAKA}

Adinugroho, G., 2017. Hubungan Perkembangan Wisata terhadap Ekonomi Wilayah di Gunungkidul Selatan The Impact of Tourism Development towards Regional Economy at. Journal of Regional and Rural Development Planning, 1(1), 16-27.

BPS, \& Kominfo., 2016, Indeks Pembangunan Manusia Gunung Kidul Human Development Index. Yogyakart.

Falah, N. , 2014, Efektivitas outbound sebagai Metode Pembelajaran (Studi Pada Out Bound Mahasiswa Jurusan BKI Fakultas Dakwah dan Komunikasi UIN Sunan Kalijaga Yogyakarta). Jurnal Hisbah, 11(1), 53-75.

Irwanto, D. , 2017, Peristiwa _ Pesona Gunung Gentong Gedangsari Gunungkidul.

Nafisah, A., \& Sukarniati, L., 2015, Dampak Perkembangan Pariwisata Kabupaten Gunung Kidul Terhadap Kondisi Ekonomi Masyarakat Sekitar. JURNAL BISNIS \& EKONOMI, 13(2), 105-115.

Pemkab Gunungkidul., 2016, kondisi geografi _ pemerintahangunungkidul.

Sari, M., 2016, Membangkitkan Kembali Tradisi Dolanan Anak Sebagai Upaya Penanaman Nilai Nilai Karakter di Sekolah Dasar. Jurnal PPKn \& Hukum, 11(1), 86-97.

Suripto., 2011, Pembangunan Manusia Untuk Mewujudkan Masyarakat Kalimantan Timur Berkualitas. Jurnal Borneo Administrator, 7(3), 258-282.

\section{UCAPAN TERIMAKASIH}

Terima kasih diucapkan kepada :

1. Universitas Ahmad Dahlan sebagai penyumbang dana sehingga kegiatan PKM ini dapat berjalan dengan baik. 
2018 Jurnal Pemberdayaan: Publikasi Hasil Pengabdian kepada Masyarakat - ISSN: 2088 4559; e-ISSN:

2. Pemerintah Desa Ngalang yang telah memberikan dukungan dan bantuan selama proses pelaksanaan kegiatan PKM.

3. Forum Remaja Desa Ngalang yang sangat aktif berperan dalam pelaksanaan program. 
2018 Jurnal Pemberdayaan: Publikasi Hasil Pengabdian kepada Masyarakat - ISSN: 2088 4559; e-ISSN:

Wisata outbound di gunung Gentong Gedangsari Gunung Kidul (Tri Wahyuni Sukesi) | 274 